\title{
PENERAPAN SISTEM INFORMASI KALENDAR TANAM ( SI KATAM) MENDUKUNG PENINGKATAN INDEKS PERTANAMAN PADI KABUPATEN INDRAGIRI HULU
}

\section{Implementation of the Planting Calendar Information System (SI Katam) Supports the Increase of the Rice Planting Index of Indragiri Hulu Regency}

\author{
Anis Fahri, Syuryati, Ade Yulfida dan Rachmiwati Yusuf \\ Balai Pengkajian Teknologi Pertanian Riau Jl. Kaharuddin Nasution 346, km 10. Pekanbaru. \\ Email: anisfahri@gmail.com
}

\begin{abstract}
Integrated Planting Calendar Information System becomes a necessity, which is expected to increase agricultural yields and can reduce crop losses due to drought and floods. Besides that, an information that is summarized in one data base becomes a need to get various information in quick time. This planting calendar provides a complete information for farmers. These operational guidelines are established at the community and sub-district levels. Planting Calendar Information System as an important tool in adjusting cropping patterns with climate change. Deliver information about the direction, strategies and policies of the agricultural sector on climate change in the form of a road map to stakeholders and related parties. This paper aims to find out the application of water resources and climate in supporting the improvement of Indragiri Hulu Regency's rice crop index. The methodology used is through field observations and secondary data collection. The Research and Development Agency has developed adaptive technology with climate change, namely the Integrated Planting Calendar Information System (KATAM). The results showed that referring to the Recapitulation of Rice Potential Calendar for Indragiri Hulu Regency in the planting season MH 2017/2018 and MK April - September 2018 it was known that the area of rice planting was 5.029 ha with a Planting Index of $269 \%$. The recommended potential for SI Katam Integrated rice was 862 ha wider than the existing planting area of 4.167 ha with an IP value of $118 \%$.
\end{abstract}

Keywords: Information system, integrated planting calendar, climate change, rice cropping index

\begin{abstract}
ABSTRAK
Sistem Informasi Kalender Tanam Terpadu menjadi sebuah kebutuhan, yang diharapkan dapat meningkatkan hasil pertanian dan dapat mengurangi kerugian panen akibat kekeringan dan banjir. Disamping itu sebuah informasi yang terangkum dalam satu data base menjadi sebuah kebutuhan untuk mendapatkan berbagai informasi dalam waktu cepat. Kalender tanam ini memberikan informasi yang lengkap bagi petani. Panduan operasional tersebut ditetapkan pada level masyarakat, dan kecamatan. SI KATAM sebagai salah satu alat penting dalam penyesuaian pola tanam tanaman pangan dengan perubahan iklim. Menyampaikan informasi tentang arah, strategi dan kebijakan sektor pertanian terhadap perubahan iklim berupa road map kepada pemangku kepentingan dan pihak terkait. Makalah ini bertujuan untuk mengetahui penerapan sumberdaya air dan iklim dalam mendukung peningkatan indeks pertanaman padi Kabupaten Indragiri Hulu. Metodologi yang digunakan yakni melalui observasi lapang dan pengumpulan data sekunder. Badan Litbang telah menyusun teknologi adaptif dengan perubahan iklim yaitu Sistem Informasi Kalender Tanam (KATAM) Terpadu. Hasil penelitian menunjukkan mengacu kepada Rekapitulasi Kalender Potensi Tanam Padi Kabupaten Indragiri Hulu musim tanam MH 2017/2018 dan MK April - September 2018 diketahui luas tanam padi seluas 5.029 hektar dengan Indeks Pertanaman sebesar 269\%. Rekomendasi potensi tanam padi SI Katam Terpadu lebih luas seluas 862 ha dibandingkan dengan luas tanam existing yakni 4.167 ha dengan nilai IP $118 \%$.
\end{abstract}

Kata Kunci: Sistem informasi, kalender tanam terpadu, perubahan iklim, indeks pertanaman padi 


\section{PENDAHULUAN}

Perubahan iklim global yang berimbas terhadap pola hujan menjadi kendala bagi Program Peningkatan Produksi Beras Nasional (P2BN) dan Program Peningkatan Produksi Padi. Perubahan iklim yang ditandai oleh perubahan pola dan distribusi curah hujan (Surfleet dan Tullos, 2013), peningkatan suhu udara (Gunawardhana dan Kazama 2012), dan peningkatan permukaan air laut (Zecca dan Chiari, 2012) berdampak secara langsung dan tidak langsung terhadap wilayah pertanian (Kang et al. 2009). Salah satu implikasi dari perubahan iklim adalah pergeseran awal dan akhir musim tanam yang berdampak negatif terhadap pola tanam dan produktivitas tanaman, khususnya tanaman semusim.

Naylor et al. (2007) dalam Runtunuwu et al. (2103) secara spesifik menyatakan bahwa produksi pertanian di Indonesia sangat dipengaruhi oleh curah hujan, baik variasi antarmusim maupun antartahun, akibat dari monsoon Australia-Asia dan El Nino-Southern Oscillation (ENSO) yang dinamis. Untuk memandu petani dalam menyesuaikan waktu dan pola tanam, Badan Penelitian dan Pengembangan (Balitbang) Pertanian, Kementerian Pertanian sejak tahun 2007 telah menyusun informasi kalender tanam tanaman padi setiap kecamatan untuk seluruh Indonesia dalam bentuk atlas. Atlas Kalender Tanam Tanaman Pangan Skala 1:250.000 yang telah dibuat adalah pulau: Jawa (Las et al. 2007; Runtunuwu et al. 2011a), Sumatera (Las et al. 2008). Peta ini menggambarkan potensi pola tanam dan waktu tanam tanaman semusim, terutama padi, berdasarkan potensi dan dinamika sumber daya iklim dan air.

Peraturan Menteri Pertanian (Permentan) No. 45/ 2011 tentang Tata Hubungan Kerja Antara Kelembagaan Teknis, Penelitian dan Pengembangan, dan Penyuluhan Pertanian dalam Mendukung Pening-katan Produksi Beras Nasional (P2BN) menjelaskan bahwa Badan Litbang Pertanian bertanggung jawab antara lain dalam pengembangan dan penerapan kalender tanam, baik dalam penyusunan, sosialisasi, validasi lapang, maupun upaya adaptasi dan mitigasi perubahan iklim. Sejalan dengan Permentan No. 45/ 2011, Badan Litbang Pertanian mengembangkan Sistem Informasi
Kalender Tanam Terpadu (selanjut-nya disingkat SI Katam Terpadu) yang menjadi rujukan bagi pengambil kebijakan dalam penyusunan rencana pengelolaan pertanian tanaman pangan skala kecamatan (Ramadhani et al. 2012; Runtunuwu et al. 2012a). SI Katam Terpadu dapat diakses melalui alamat situs web litbang.deptan.go.id, deptan.go.id, epetani. deptan.go.id, balitklimat.litbang. deptan.go.id, dan katam.info.

Untuk melaksanakan Permentan No. 45/2011, Kepala Badan Litbang Pertanian menerbitkan Surat Keputusan (SK) No. 77.1/Kpts/OT.160/I/3/2012 tentang Tim Penyusunan Kalender Tanam Terpadu (selanjutnya disebut Tim Katam Pusat) dan SK No. 178 /Kpts/OT.160/I/7/2012 tentang Pembentukan Gugus Tugas Katam dan Perubahan Iklim di Balai Pengkajian Teknologi Pertanian (selanjutnya disebut Gugus Tugas BPTP). Pembentukan kedua tim ini sangat penting karena efektivitas pelaksanaan Permentan No. 45/2011 sangat bergantung pada keakuratan, kelengkapan, dan kecepatan arus data dan informasi dan sistem informasi yang andal.

Untuk memudahkan dan mengoptimalkan pelak-sanaan kegiatan Tim Katam Pusat dan Gugus Tugas BPTP telah disusun Petunjuk Teknis Gugus Tugas Kalender Tanam Terpadu dan Perubahan Iklim (Badan Litbang Pertanian 2013a) dan Petunjuk Teknis Pengelolaan Stasiun Iklim (Badan Litbang Pertanian 2013b), agar masing-masing memiliki kerangka kerja yang jelas, baik dalam pelaksanaan teknis kegiatan maupun koordinasi dan komunikasi. Makalah ini berisi ringkasan petunjuk teknis Gugus Tugas Kalen-der Tanam Terpadu dan Perubahan Iklim sebagai penguatan Permentan No. 45/2011 serta implikasi kebijakannya. Makalah ini bertujuan untuk mengetahui potensi peningkatan Indeks Pertanaman padi melalui penerapan Sistem Informasi Kalender Tanam (SI-KATAM) terpadu dalam rangka mendukung upaya pemerintah untuk meningkatkan produksi padi nasional menuju swasembada beras.

\section{METODE PENELITIAN}

Penelitian dilaksanakan pada bulan Januari - Desember 2018, yang berlokasi di 
Kabupaten Indragiri Hulu. Penelitian ini dilaksanakan melalui study pustaka, menggunakan data sekunder. BPS Kabupaten Indragiri Hulu, Dinas Pertanian Tanaman Pangan dan Perkebunan Kabupaten Indrgiri Hulu BMKG Provinsi Riau dan instansi lain yang terkait.

\section{HASIL DAN PEMBAHASAN}

\section{Sistem Informasi KATAM Terpadu}

Peta kalender tanam disusun berdasarkan kondisi aktual di lapang dan kondisi potensial dengan menggunakan analisis klimatologis. Kondisi aktual diketahui dari luas tanam dan intensitas penanaman, sedangkan kondisi potensial disimpulkan melalui analisis ketersediaan air berdasarkan curah hujan seperti pada gambar di bawah ini.

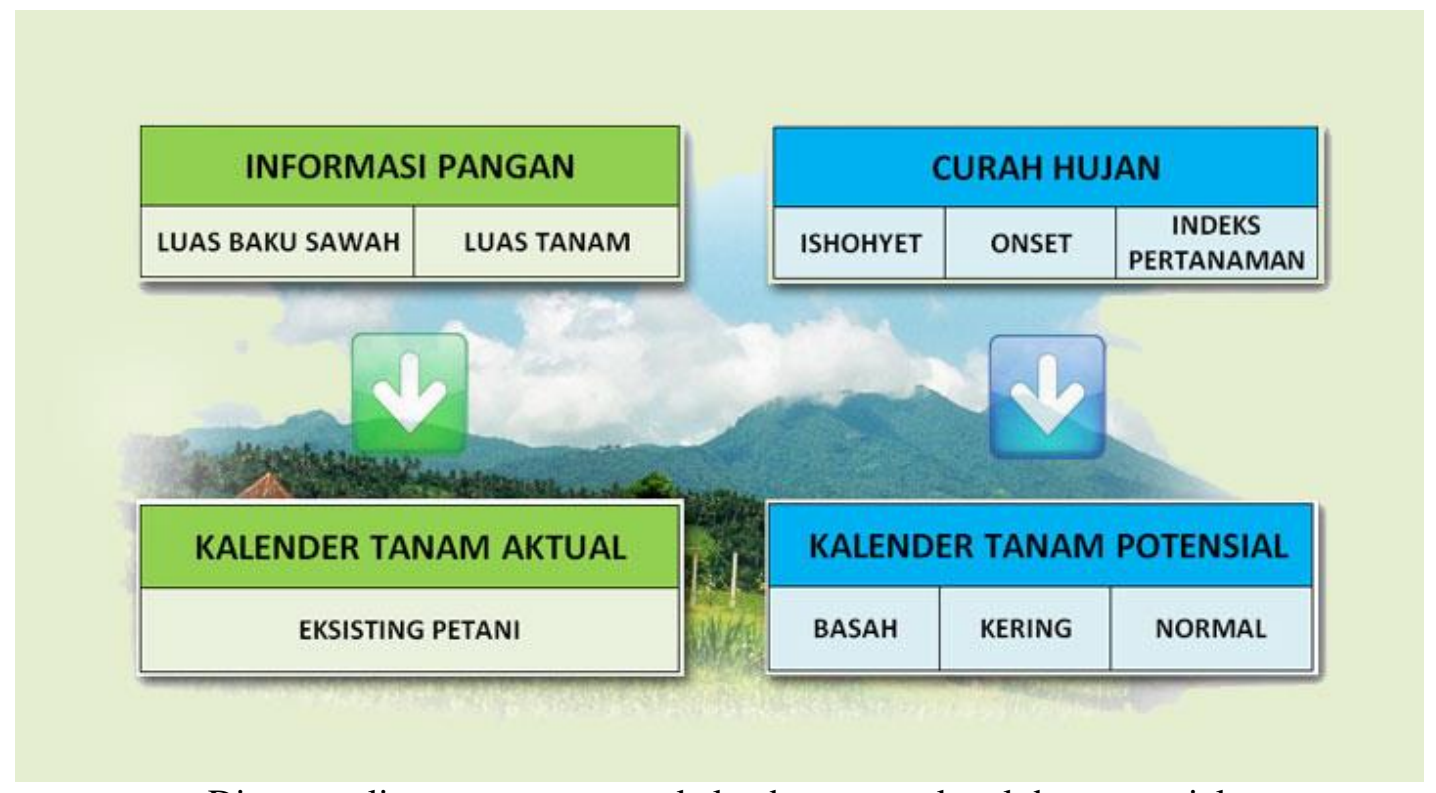

Diagram alir penyusunan peta kalender tanam aktual dan potensial

Penyusunan kalender tanam aktual menggambarkan kalender tanam yang umumnya dilakukan petani selama ini. Analisis dilakukan dengan menggunakan data luas tanam rata-rata sepuluh harian per kecamatan untuk periode lima sampai sembilan tahun terakhir tergantung ketersediaan data di setiap provinsi. Awal tanam MT I ditentukan pada saat $8 \%$ dari luas baku sawah kecamatan yang bersangkutan telah ditanami padi. Awal tanam MT II ditentukan pada saat $6 \%$ dari luas baku sawah telah ditanami padi. Sedangkan awal tanam MT III ditentukan pada saat $2 \%$ dari luas baku sawah telah ditanami padi. Penyusunan kalender tanam potensial menggunakan informasi iklim/curah hujan sebagai parameter utama di dalam penentuan onset musim tanam. Komponen utama deliniasi kalender tanam adalah curah hujan dan ketersediaan air irigasi. Kegiatan yang dilakukan pada tahap awal adalah menginventarisasi data sumberdaya iklim, terutama curah hujan, yang kemudian dianalisis untuk menentukan karakteristik curah hujan, yaitu variabilitas iklim, zona agroklimat, potensi awal musim tanam (onset), dan intensitas pertanaman (IP).

Pengemasan SI Katam Terpadu dirintis Badan Litbang Pertanian sejak tahun 2007 melalui penyusunan informasi kalender tanam tanaman padi setiap kecamatan untuk seluruh Indonesia dalam bentuk atlas. Atlas Kalender Tanam Tanaman Pangan skala 1:250.000 yang telah dibuat meliputi Pulau Jawa (Las et al. 2007; Runtunuwu et al. 2011a), Sumatera (Las et al. 2008; Runtunuwu et al. 2011b), Kalimantan (Las et al. 2009a; Runtunuwu et al. 2012b), Sulawesi (Las et al. 2009b; Runtunuwu et al. 2012c), serta Bali, Maluku, Nusa Tenggara, dan Papua (Las et al. 2010; Runtunuwu et al. 2013).

Peran strategis SI Katam Terpadu dalam adaptasi perubahan iklim tercermin dari 
kemampuan SI ini dalam menginformasikan kondisi musim tanam ke depan, yang meliputi awal waktu tanam tanaman pangan, wilayah rawan bencana banjir, kekeringan, dan organisme pengganggu tanaman (OPT), serta rekomendasi teknologi berupa varietas, benih, dan pemupukan berimbang. Katam Terpadu berbasis web pertama kali diluncurkan secara resmi oleh Kepala Badan Litbang Pertanian pada 27 Desember 2011 dengan diterbitkannya secara online SI Katam Terpadu ver 1.0 yang memuat informasi Katam Terpadu Musim Tanam I (MT-I) 2011/2012. Sejak saat itu, SI Katam terpadu ver 1.0 telah diperbarui lima kali serta diperbaiki dan disempurnakan. Badan Litbang Pertanian memperbarui informasi ini minimal tiga kali setahun pada setiap awal musim tanam untuk seluruh kecamatan di Indonesia.

Setiap atlas kalender tanam berisi informasi estimasi awal waktu tanam dan potensi luas tanam tanaman padi setiap musim tanam (Runtunuwu dan Syahbuddin, 2011). Estimasi dilakukan berdasarkan kondisi curah hujan pada saat berlebih (basah), normal, ataupun kurang (kering). Pengelompokan curah hujan ini mengikuti kriteria sifat hujan yang dirumuskan oleh Badan Meteorologi Klimatologi dan Geofisika (BMKG, 2012).

Pengembangan Kalender tanam terpadu menjadi sebuah kebutuhan, yang diharapkan dapat meningkatkan hasil pertanian dan dapat mengurangi kerugian panen akibat kekeringan dan banjir. Kalender tanam ini memberikan informasi yang lengkap bagi petani. Panduan operasional tersebut ditetapkan pada level masyarakat, dan kecamatan.Syarat utama menggunakan informasi kalender tanam adalah pengguna perlu mengetahui musim tanam (MT) ke depan (MT I atau MT II atau MT III), dan sifat hujan musim tersebut (basah atau normal atau kering). Kelompok musim tanam kedepan dapat ditetapkan dengan mudah menggunakan periode waktu. MT I mulai September III/Oktober I sampai dengan Januari III/Februari I, MT II mulai Februari II/III sampai dengan Mei III/Juni I, dan mulai Juni II/III sampai September I/II. Di sisi lain, sifat hujan dapat diketahui dari BMKG yang mengeluarkan prakiraan sifat hujan bulanan dan musiman secara reguler setiap tahun. Atlas kalender tanam belum memuat informasi prakiraan sifat hujan ini sehingga pengguna belum dapat secara langsung menentukan awal waktu tanam musim tanam kedepan ( Runtunuwu, et al. 2012).

Tabel 1. Luas lahan, luas tanam, luas panen, produksi dan Indeks Pertanaman padi Kabupaten Indragiri Hulu. 2018

\begin{tabular}{llrrrrc}
\hline No & \multicolumn{1}{c}{$\begin{array}{c}\text { Kecamatan } \\
\text { (ha) }\end{array}$} & & $\begin{array}{c}\text { Luas } \\
\text { Tanam (ha) }\end{array}$ & $\begin{array}{c}\text { Luas } \\
\text { Panen } \\
\text { (ha) }\end{array}$ & $\begin{array}{c}\text { Produksi } \\
\text { (Ton) }\end{array}$ & $\begin{array}{c}\text { Indeks } \\
\text { Pertanaman } \\
(\%)\end{array}$ \\
\hline 1 & Peranap & 213 & 89 & 88 & 422,10 & 41 \\
2 & Batang Peranap & 36 & 22 & 8 & 793,95 & 61 \\
3 & Seberida & 8 & 7 & 14 & 46,90 & 88 \\
4 & Batang Cenaku & 16 & 0 & 0 & 0 & 0 \\
5 & Batang Gangsal & 14 & 0 & 0 & 0 & 0 \\
6 & Kelayang & 225 & 85 & 125 & 418,75 & 38 \\
7 & Rakit Kulim & 579 & 174 & 273 & $1.149,05$ & 3 \\
8 & Pasir Penyu & 33 & 0 & 0 & 0 & 0 \\
9 & Lirik & 0 & 0 & 0 & 0 & 0 \\
10 & Sei Lala & 99 & 0 & 0 & 0 & 0 \\
11 & Lubuk Batu Jaya & 0 & 0 & 0 & 0 & 0 \\
12 & Rengat & 118 & 4 & 4 & 13,40 & 3 \\
13 & Rengat Barat & 249 & 92 & 92 & 308,20 & 36 \\
14 & Kuala Cenaku & 1.947 & 3.694 & 3.163 & $10.598,05$ & 189 \\
\hline & Junlah & 3.537 & 4.167 & 3.765 & $16.773,45$ & 118 \\
\hline
\end{tabular}

Distan Pertanian TPH Kabupaten Indragiri Hulu, 2018. 
Dalam lima tahun terakhir luas lahan sawah kabupaten Indragiri Hulu mengalami penurunan yakni pada tahun 2014 seluas 6.695 hektar menjadi seluas 3.537 hektar pada tahun 2018. Intensitas pertanaman padi (IP) hingga saat ini masih pada rata-rata 100 bertanam dalam setahun. Produktivitas tanaman yang masih rendah yakni sekitar 3,35 ton/ha (Distan TPH dan Perkebunan Indragiri Hulu 2018). Sumber pengairan lahan sawah di Kabupaten Indragiri Hulu, terutama daerah sentra produksi padi pada umumnya berasal dari air pasang surut Sungai Indragiri, sebahagian lagi dari tadah hujan. Pemanfaatan lahan sawah pada masing-masing kecamatan dapat dilihat pada Tabel 1.

\section{Kesesuaian Potensi Tanam}

Usaha yang dapat dilakukan adalah
menyesuaikan pengembangan pertanian yang toleran terhadap perubahan iklim, antara lain melalui penyesuaian

waktu dan pola tanam, penggunaan varietas yang adaptif, tahan terhadap organisme penganggu tanaman (OPT), dan pengelolaan air secara efisien.

Tabel 2. Rekapitulasi Kalender Potensi Tanam Padi Kabupaten Indragiri Hulu

\begin{tabular}{|c|c|c|c|c|c|c|c|c|c|c|}
\hline \multirow{3}{*}{ No } & \multirow{3}{*}{ Kecamatan } & \multirow{3}{*}{$\begin{array}{l}\text { Indeks } \\
\text { Adm }\end{array}$} & \multirow{3}{*}{$\begin{array}{l}\text { Luas } \\
\text { baku } \\
\text { sawah } \\
\text { (ha) }\end{array}$} & \multicolumn{4}{|c|}{$\begin{array}{c}\text { MH 2018/MH } 2018 \text { (Okt } 2018 \text { - } \\
\text { Maret 2019) }\end{array}$} & \multirow{2}{*}{\multicolumn{2}{|c|}{$\begin{array}{c}\text { MK } 2019 \text { (April - } \\
\text { Sept 2019) } \\
\text { MK2: }\end{array}$}} & \multirow{3}{*}{$\begin{array}{l}\text { Indeks } \\
\text { Pertana } \\
\text { man } \\
(\%)\end{array}$} \\
\hline & & & & \multicolumn{2}{|c|}{ MH1 : MT1 } & \multicolumn{2}{|c|}{ MK1 : MT3 } & & & \\
\hline & & & & $\begin{array}{c}\text { Awal } \\
\text { waktu } \\
\text { tanam }\end{array}$ & $\begin{array}{l}\text { Luas } \\
\text { (ha) }\end{array}$ & $\begin{array}{l}\text { Awal } \\
\text { waktu } \\
\text { tanam }\end{array}$ & $\begin{array}{l}\text { Luas } \\
\text { (ha) }\end{array}$ & $\begin{array}{l}\text { Awal } \\
\text { waktu } \\
\text { tanam }\end{array}$ & $\begin{array}{l}\text { Luas } \\
\text { (ha) }\end{array}$ & \\
\hline 1 & Peranap & 1402010 & 124 & $\begin{array}{l}\text { JAN I- } \\
\text { II }\end{array}$ & 113 & MEI I-II & 124 & $\begin{array}{l}\text { SEP I - } \\
\text { II }\end{array}$ & 124 & 291 \\
\hline 2 & $\begin{array}{l}\text { Batang } \\
\text { Peranap }\end{array}$ & 1402011 & 18 & $\begin{array}{l}\text { JAN I- } \\
\text { II }\end{array}$ & 18 & MEI I-II & 18 & $\begin{array}{l}\text { SEP I - } \\
\text { II }\end{array}$ & 18 & 300 \\
\hline 3 & Seberida & 1402020 & 3 & $\begin{array}{l}\text { JAN I- } \\
\text { II }\end{array}$ & 3 & MEI I-II & 3 & $\begin{array}{l}\text { SEP I - } \\
\text { II }\end{array}$ & 2 & 267 \\
\hline 4 & $\begin{array}{l}\text { Batang } \\
\text { Cenaku }\end{array}$ & 1402021 & 0 & $\begin{array}{c}\text { Tidak } \\
\text { ada } \\
\text { sawah }\end{array}$ & 0 & MEI I-II & 0 & $\begin{array}{l}\text { Tidak } \\
\text { ada } \\
\text { sawah }\end{array}$ & 0 & 0 \\
\hline 5 & $\begin{array}{l}\text { Batang } \\
\text { Gangsal }\end{array}$ & 1402022 & 33 & $\begin{array}{c}\text { JAN I- } \\
\text { II }\end{array}$ & 30 & MEI I-II & 33 & $\begin{array}{c}\text { SEP I - } \\
\text { II }\end{array}$ & 33 & 291 \\
\hline 6 & Kelayang & 1402030 & 112 & $\begin{array}{l}\text { JAN I- } \\
\text { II }\end{array}$ & 101 & MEI I-II & 112 & $\begin{array}{l}\text { SEP I - } \\
\quad \text { II }\end{array}$ & 82 & 263 \\
\hline 7 & Rakit Kulim & 1402031 & 236 & $\begin{array}{l}\text { JAN I- } \\
\text { II }\end{array}$ & 212 & MEI I-II & 146 & $\begin{array}{l}\text { SEP I - } \\
\text { II }\end{array}$ & 236 & 252 \\
\hline 8 & Pasir Penyu & 1402040 & 0 & $\begin{array}{l}\text { Tidak } \\
\text { ada } \\
\text { sawah }\end{array}$ & 0 & MEI I-II & 0 & $\begin{array}{l}\text { Tidak } \\
\text { ada } \\
\text { sawah }\end{array}$ & 0 & 0 \\
\hline 9 & Lirik & 1402041 & 0 & $\begin{array}{l}\text { Tidak } \\
\text { ada } \\
\text { sawah }\end{array}$ & 0 & MEI I-II & 0 & $\begin{array}{l}\text { Tidak } \\
\text { ada } \\
\text { sawah }\end{array}$ & 0 & 0 \\
\hline 10 & Sungai Lala & 1402042 & 41 & $\begin{array}{l}\text { JAN I- } \\
\text { II }\end{array}$ & 41 & MEI I-II & 41 & $\begin{array}{l}\text { SEP I - } \\
\text { II }\end{array}$ & 41 & 300 \\
\hline 11 & $\begin{array}{l}\text { Lubuk Batu } \\
\text { Jaya }\end{array}$ & 1402043 & 0 & $\begin{array}{c}\text { Tidak } \\
\text { ada } \\
\text { sawah }\end{array}$ & 0 & MEI I-II & 0 & $\begin{array}{l}\text { Tidak } \\
\text { ada } \\
\text { sawah }\end{array}$ & 0 & 0 \\
\hline 12 & Rengat Barat & 1402050 & 127 & $\begin{array}{c}\text { JAN I- } \\
\text { II }\end{array}$ & 114 & MEI I-II & 127 & $\begin{array}{c}\text { SEP I - } \\
\text { II }\end{array}$ & 127 & 290 \\
\hline 13 & Rengat & 1402060 & 5 & $\begin{array}{l}\text { JAN I- } \\
\text { II }\end{array}$ & 5 & MEI I-II & 4 & $\begin{array}{l}\text { SEP I - } \\
\quad \text { II }\end{array}$ & 2 & 220 \\
\hline 14 & $\begin{array}{l}\text { Kuala } \\
\text { Cenaku }\end{array}$ & 1402061 & 1.167 & $\begin{array}{l}\text { JAN I- } \\
\text { II }\end{array}$ & 1.050 & MEI I-II & 922 & $\begin{array}{l}\text { SEP I - } \\
\text { II } \\
\end{array}$ & 1.167 & 269 \\
\hline Jum & & & 1.866 & & 1.687 & & 1.530 & & 1.832 & 269 \\
\hline
\end{tabular}


Usahatani padi yang dilakukan hanya satu kali dalam setahun yaitu penanaman padi dilakukan, dengan pola tanam padi - bera atau padi - palawija. Namun pola tanam padi - bera lebih dominan dibandingkan dengan pola tanam padi-palawija. Upaya meningkatkan produktivitas lahan dan sekaligus kesejahteraan petani, perlu suatu strategi/program yang didukung oleh teknologi tepat guna yang mengarah pada perbaikan pengelolaan usahatani melalui peningkatan produktivitas dan efisiensi usahatani, serta sekaligus mempertahankan kesuburan tanah melalui tindakan konservasi tanah dan air (Abdurachman, 2005).

Rekomendasi pupuk mempertimbangkan kondisi status hara tanah aktual di lapangan dan kebutuhan hara tanaman. Informasi status hara fosfat (P) dan kalium (K) aktual dalam tanah dapat diperoleh dengan menggunakan Perangkat Uji Tanah Sawah (PUTS), analisis tanah secara langsung di laboratorium, dan Peta Status Hara Tanah P dan K Tanah Sawah skala 1:50.000. Berdasarkan nilai uji tanah/status hara N, P, K tersebut, ditetapkan dosis pupuk untuk padi sawah.

Rekomendasi pupuk untuk tanaman padi VUB atau hibrida diprediksi sekitar 20\% lebih tinggi dibandingkan dengan varietas unggul biasa. Apabila informasi status hara tanah tidak tersedia, maka dosis pupuk dapat mengacu pada rekomendasi pupuk PHSL atau Permentan No. 40/2007 dan revisinya atau acuan rekomendasi lain yang dianjurkan oleh Dinas/ Bakorluh/BPTP setempat. Informasi rekomendasi pupuk dalam revisi Permentan No. 40/2007 memberikan pilihan untuk menggunakan pupuk tunggal atau pupuk NPK majemuk yang dikombinasikan dengan pupuk organik.

\section{Pola Tanam dan Penataan Lahan}

Lahan sawah Kabupaten Indragiri Hulu seluas 3.537 hektar terdiri dari 2.111 hektar lahan sawah tadah hujan dan 1.426 ha lahan rawa pasang surut. Sebagian besar berada disepanjang daerah aliran sungai (DAS) Indragiri. Areal pasang surut yang sesuai untuk pengembangan tanaman padi adalah wilayah yang memiliki tipe genangan air $\mathrm{A}, \mathrm{B}$, dan $\mathrm{C}$ dengan sistem surjan dan hamparan. Pola tanam dengan penataan lahan sawah pada tipe luapan A adalah padi-padi. Sedangkan pola tanam dengan penataan lahan sawah atau surjan pada tipe luapan air B adalah padi-padi dan padipalawija/hortikultura.

Tabel 4. Acuan penataan lahan masing-masing tipologi lahan dan tipe luapan air di lahan pasang surut

\begin{tabular}{|c|c|c|c|c|}
\hline \multirow[t]{2}{*}{ Tipologi Lahan } & \multicolumn{4}{|c|}{ Tipe luapan air } \\
\hline & $\mathrm{A}$ & $\mathrm{B}$ & $\mathrm{C}$ & $\mathrm{D}$ \\
\hline Potensial & Sawah & Sawah/ Surjan & Sawah/surjan/tegalan & Sawah/tegalan/ kebun \\
\hline Sulfat Masam & Sawah & Sawah/ Surjan & Sawah/surjan/tegalan & Sawah/tegalan/ kebun \\
\hline Bergambut & Sawah & Sawah/ Surjan & Sawah/surjan/tegalan & Sawah/tegalan/ kebun \\
\hline Gambut Dangkal & Sawah & Sawah/ Surjan & Sawah/surjan/tegalan & Sawah/tegalan/ kebun \\
\hline Gambut Sedang & Sawah & Konservasi & Tegalan/ Perkebunan & Perkebunan \\
\hline Gambut Dalam & Sawah & Konservasi & Tegalan/ Perkebunan & Perkebunan \\
\hline Salin & Sawah/tambak & Sawah/ Tambak & - & - \\
\hline
\end{tabular}

Sumber ; Widjaya Adhi (1995) dan Alihamsyah et al. (2000)

Produktivitas padi kabupaten Indragiri Hulu masih rendah sekitar 3,35 ton/ha dan ratarata indek pertanaman (IP) 118. Peningkatan produksi padi dapat dicapai melalui peningkatan kuantitas pertanaman yakni melalui perluasan areal dan peningkatan indeks pertanaman (IP). Sedangkatan peningkatan produktivitas melalui penggunaan benih varietas unggul baru, peningkatan jaringan irigasi, pemupukan sesuai kebutuhan hara tanaman, pemeliharaan tanaman (pengendalian organisma pengganggu tanaman) dan menekan kehilangan hasil padi pada saat panen.

Peningkatan produksi padi mencapai 5-6 melalui introduksi teknologi padi seperti benih unggul, VUB, pemupukan, ameliorasi, pengendalian OPT (Ismail et al., 1993 dan Alihamsyah et al., 2003). Menurut Abdullah et al. (2008), Salah satu penyebab rendahnya produksi padi adalah telah tercapainya potensi hasil optimum dari varietas unggul baru (VUB) yang ditanam oleh petani atau terbatasnya kemampuan genetik varietas unggul yang ada untuk berproduksi lebih tinggi (Balitpa, 2003). 
Mengacu kepada Rekapitulasi Kalender Potensi Tanam Padi Kabupaten Indragiri Hulu Indeks pertanaman musim tanam $\mathrm{MH}$ 2018/2019 (Oktober 2018 - Maret 2019) dan MK 2019 diperoleh Indeks Pertanaman padi

Tabel 3. Kesesuaian Luas Potensi Tanam padi Existing dan Rekomendasi Katam MH 2018/2019 dan MK 2019.

\begin{tabular}{llrcrcc}
\hline No & \multicolumn{1}{c}{ Kecamatan } & $\begin{array}{c}\text { Luas Tanam } \\
\text { Existing }\end{array}$ & $\begin{array}{c}\text { Indeks } \\
\text { Pertanaman } \\
(\%)\end{array}$ & $\begin{array}{c}\text { Luas } \\
\text { Tanam } \\
\text { Katam } \\
\text { (ha) }\end{array}$ & $\begin{array}{c}\text { Indeks } \\
\text { Pertanaman } \\
(\%)\end{array}$ & Persentase $(\%)$ \\
\hline 1 & Peranap & 88 & 41 & 361 & 291 & 30,24 \\
2 & Batang Peranap & 8 & 61 & 54 & 300 & 2,67 \\
3 & Seberida & 14 & 88 & 8 & 267 & 5,24 \\
4 & Batang Cenaku & 0 & 0 & 0 & 0 & 0 \\
5 & Batang Gangsal & 0 & 0 & 0 & 291 & 0 \\
6 & Kelayang & 125 & 38 & 295 & 263 & 108,33 \\
7 & Rakit Kulim & 273 & 3 & 594 & 252 & 0 \\
8 & Pasir Penyu & 0 & 0 & 0 & 0 & 0 \\
9 & Lirik & 0 & 0 & 0 & 0 & 0 \\
10 & Sei Lala & 0 & 0 & 123 & 300 & 0 \\
11 & Lubuk Batu Jaya & 0 & 0 & 0 & 0 & 1,38 \\
12 & Rengat & 4 & 3 & 368 & 290 & 41,82 \\
13 & Rengat Barat & 92 & 36 & 11 & 220 & 1,18 \\
14 & Kuala Cenaku & 3.163 & 189 & 3.139 & 269 & 1,40 \\
\hline
\end{tabular}

\section{KESIMPULAN}

1. Lahan sawah pasang surut Kabupaten Indragiri Hulu memiliki potensi dan prospek yang besar untuk pengembangan pertanian, khususnya dalam mendukung ketahanan pangan nasional. Mengacu kepada Rekapitulasi Kalender Potensi Tanam Padi Kabupaten Indragiri Hulu Indeks pertanaman musim tanam MH 2018/2019 (Oktober 2018 - Maret 2019) dan MK 2019 diperoleh Indeks Pertanaman padi sebesar $269 \%$.

2. Dengan meningkatnya Indeks Pertanaman dan penggunaan pupuk sesuai rekomendasi diharapkan peluang peningkatan hasil sebesar $169 \%$.

3. Badan Litbang Pertanian telah menghasilkan Sistem Informasi Kalender Tanam Terpadu ver 1.3 yang diakses melalui litbang.pertanian.go.id atau balitklimat.litbang.pertanian go.id. Sistem ini merupakan pedoman atau alat bantu yang memberikan informasi spasial dan tabular tentang prediksi musim, awal tanam, pola tanam, luas tanam potensial, wilayah rawan banjir dan kekeringan, potensi serangan OPT, varietas padi dan kebutuhan benih, sebesar $269 \%$. Dengan meningkatnya Indeks Pertanaman dan penggunaan pupuk sesuai rekomendasi diharapkan akan diikuti dengan peningkatan hasil sebesar $167 \%$. 
temperatures: The impacts of climate change on aquifer thermal regimes. Global Planet. Change 86-87: 66-78.

Kang, Y., S. Khan, and X. Ma. 2009. Climate change impacts on crop yield, crop water productivity and food security - A review. Progress Nat. Sci. 19(12): 16651674.

Las, I., A. Unadi, K. Subagyono, H. Syahbuddin, dan E. Runtunuwu. 2007. Atlas Kalender Tanam Pulau Jawa Skala 1:1.000.000 dan 1:250.000. Balai Penelitian Agroklimat dan Hidrologi, Bogor.

Las, I., A. Unadi, H. Syahbuddin, dan E. Runtunuwu. 2008. Atlas Kalender Tanam Pulau Sumatera Skala 1:1.000.000 dan 1:250.000. Balai Penelitian Agroklimat dan Hidrologi, Bogor.

[LITBANG]. Badan Litbang Kementerian Pertanian Republik Indonesia. 2017. KalenderTanamJakarta. http://balitklimat.litbang.deptan.go.id/we bkatam/main.html

Surfleet, Ch.G. and D. Tullos. 2013. Variability in effect of climate change on rain-onsnow peak flow events in a temperate climate. J. Hydrol. 479: 24-34.

Ramadhani, F., E. Runtunuwu, dan H. Syahbuddin. 2012. Pengembangan sistem teknologi informasi kalender tanam terpadu berbasis web. Disampaikan kepada Jurnal Informatika Pertanian pada November 2012.

Runtunuwu, E., H Syahbuddin, Fadhlullah Ramadhani, A. Pramudia, D. Setyorini, K. Sari, Y. Apriyana, E. Susanti, dan Haryono. 2013. Inovasi kelembagaan sistem informasi kalender tanam terpadu mendukung adaptasi perubahan iklim untuk ketahanan pangan nasional. J. Pengembangan Inovasi Pertanian Vol. 6 No. 1 Maret 2013: 44-52.

Runtunuwu, E., dan H, Syahbuddin. 2011. Atlas kalender tanam tanaman pangan nasional untuk menyikapi variabilitas dan perubahan iklim. Jurnal Sumberdaya Lahan 5(1):1-10.

Runtunuwu E., H. Syahbuddin, F. Ramadhani, A. Pramudia, D. Setyorini, K. Sari, Y.Apriyana, E. Susanti, Haryono, P. Setyanto, I. Las, dan M. Sarwani. 2012. Sistem Informasi Kalender Tanam Terpadu: Status terkini dan tantangan kedepan. J. Sumberdaya Lahan Vol. 6 No. 2, Desember 2012.

Widjaya Adhi, IPG. 1995. Pengelolaan tanah dan air dalam pengembangan sumberdaya lahan rawa untuk usahatani berkelanjutan dan berwawasan lingkungan. Makalah Pada Pelatihan Calon Pelatih untuk Pengembangan Pertanian di Daerah Pasang Surut, 26-30 Juni. Karang Agung. Sumatera Selatan

Zecca, A. and L. Chiari. 2012. Lower bounds to future sea-level rise. Global Planet. Change 98-99: 1-5. 